\title{
Pharmacological and Parenteral Nutrition-Based Interventions in Microvillus Inclusion Disease
}

\author{
Changsen Leng ${ }^{1,2}$, Edmond H. H. M. Rings ${ }^{3,4}{ }^{\oplus}$, Saskia N. de Wildt ${ }^{5,6}$ and Sven C. D. van IJzendoorn ${ }^{1, *}$ \\ 1 Department of Biomedical Sciences of Cells and Systems, Section Molecular Cell Biology, University Medical \\ Center Groningen, University of Groningen, 9713 GZ Groningen, The Netherlands; \\ lengchangsen@hotmail.com \\ 2 State Key Laboratory of Oncology in South China, Collaborative Innovation Center for Cancer Medicine, \\ Guangdong Esophageal Cancer Institute, Department of Thoracic Surgery, Sun Yat-sen University Cancer \\ Center, Guangzhou 510060, China \\ 3 Department of Pediatrics, Erasmus University Medical Center, 3015 GD Rotterdam, The Netherlands; \\ e.rings@erasmusmc.nl \\ 4 Department of Pediatrics, Leiden University Medical Center, 2333 ZA Leiden, The Netherlands \\ 5 Department of Pharmacology and Toxicology, Radboud Institute Health Sciences, Radboud University \\ Medical Center, 6525 GA Nijmegen, The Netherlands; Saskia.deWildt@radboudumc.nl \\ 6 Intensive Care and Department of Pediatric Surgery, Erasmus University Medical Center, \\ 3015 GD Rotterdam, The Netherlands \\ * Correspondence: s.c.d.van.ijzendoorn@umcg.nl; Tel.: +31-(0)50-3616209
}

Citation: Leng, C.; Rings, E.H.H.M.; de Wildt, S.N.; van IJzendoorn, S.C.D. Pharmacological and Parenteral Nutrition-Based Interventions in Microvillus Inclusion Disease. J. Clin. Med. 2021, 10, 22. https:// dx.doi.org/10.3390/jcm10010022

Received: 29 November 2020 Accepted: 21 December 2020 Published: 23 December 2020

Publisher's Note: MDPI stays neutral with regard to jurisdictional claims in published maps and institutional affiliations.

Copyright: () 2020 by the authors. Licensee MDPI, Basel, Switzerland. This article is an open access article distributed under the terms and conditions of the Creative Commons Attribution (CC BY) license (https: / / creativecommons.org/ licenses/by/4.0/).
Abstract: Microvillus inclusion disease (MVID) is a rare inherited and invariably fatal enteropathy, characterized by severe intractable secretory diarrhea and nutrient malabsorption. No cure exists, and patients typically die during infancy because of treatment-related complications. The need for alternative treatment strategies is evident. Several pharmacological interventions with variable successes have been tried and reported for individual patients as part of their clinical care. Unfortunately, these interventions and their outcomes have remained hidden in case reports and have not been reviewed. Further, recent advances regarding MVID pathogenesis have shed new light on the outcomes of these pharmacological interventions and offer suggestions for future clinical research and trials. Hence, an inventory of reported pharmacological interventions in MVID, their rationales and outcomes, and a discussion of these in the light of current knowledge is opportune. Together with a discussion on MVID-specific pharmacokinetic,-dynamic, and -genetic concerns that pose unique challenges regarding pharmacological strategies, we envision that this paper will aid researchers and clinicians in their efforts to develop pharmacological interventions to combat this devastating disease.

Keywords: microvillus inclusion disease; MYO5B; myosin $\mathrm{Vb}$; congenital diarrheal disorder; malabsorption

\section{Introduction}

\subsection{Clinical Presentation}

Microvillus inclusion disease (MVID; OMIM \#251850) is an autosomal recessive congenital diarrheal disorder [1,2]. From the start of their lives, patients with MVID suffer from unstoppable secretory diarrhea at complete bowel rest (that is, in the absence of enteral feeding). The diarrhea often exceeds that seen in cholera-infected children but is variable between patients. Oral or enteral feeding is not possible and causes massive osmotic diarrhea, resulting in patients' failure to thrive [1,2].

In order to provide a detailed description of the clinical presentations of MVID, we searched EMBASE and MEDLINE databases using the following search strings: ((microvill* inclusion disease) OR (microvill* atrophy)) AND case report) to collect all published MVID case reports. Seventy valid case reports reporting on 98 patients with MVID were retrieved (Table S1). From these, information on patient gender, gestation, bodyweight at 
birth, presence or absence of polyhydramnios, day of onset, stool output, fecal analyses, and age at death, among others, were extracted and analyzed (Tables 1 and 2).

\subsection{Diagnosis}

MVID is diagnosed on the basis of the evaluation of symptoms, the exclusion of more common causes of diarrhea, and the evaluation of intestinal biopsies. Intestinal biopsies of patients with MVID reveal villus hypoplasia in the small intestine without signs of infection or inflammation [1]. Villus enterocytes display intracellular accumulation of periodic acid-Schiff (PAS)-positive material and the brush border enzyme CD10 [3,4]. Electron microscopy reveals microvillus brush border atrophy and the appearance of pathognomonic microvillus inclusions in the cytoplasm of some villus enterocytes [4]. Bi-allelic mutations in the MYO5B [5] or STX3 [6] genes can confirm MVID diagnosis. All features of MVID can also present as part of familial hemophagocytic lymphohistiocytosis, an immune disorder caused by STXBP2 gene mutations [7].

\subsection{Pathogenesis}

The proteins that are encoded by the three MVID-associated genes are functionally linked [8-10]. MYO5B, STX3, or STXBP2 mutation-driven loss of effective absorptive surface area causes malabsorption and chronic secretory diarrhea [10]. The loss of absorptive surface area includes villus hypoplasia, microvillus atrophy, and the general mislocalization (and in some cases a reduced expression) of brush border proteins. These brush border proteins include those involved in dietary nutrient digestion or absorption (e.g., lactasephlorizin hydrolase, sucrase-isomaltase, dipeptidyl peptidase IV, glucose/sodium symporter SGLT-1) [11,12] and water resorption (e.g., aquaporins) [11]. Other brush border proteins include those involved in electrolyte transport across the brush border membrane (e.g., the sodium/proton exchange protein SLC9A3 (NHE3) and the bicarbonate/chloride exchange protein SLC26A3 (DRA). The loss of MYO5B, STX3, or STXBP2 in intestinal cells, intestinal organoid cultures, or mice has been causally related to the mislocalization of these brush border proteins $[6,9,11,13,14]$ and to the loss of microvilli $[15,16]$. The consequences for the localization of the chloride/bicarbonate transporter (CFTR) are less clear. CFTR maintains its expression and brush border localization in the enterocytes of myo5bdepleted mice and some- but not all—patients $[8,14,17]$. All cellular defects appear less pronounced in the crypt area when compared to the villus area [18]. This has led to the suggestion that a defect in intestinal epithelial cell differentiation-and a resultant immature epithelium composed of predominantly secretory crypts and few absorptive villi that show (residual) chloride secreting capacity but cannot absorb sodium and chloride-underlies the symptoms. For more details on MVID pathogenesis, the reader is referred to the recent excellent review articles $[19,20]$. A cartoon illustrating key tissue and cellular defects in MVID is presented in Figure 1. 
Table 1. Clinical details from published microvillus inclusion disease (MVID) case reports.

\begin{tabular}{|c|c|c|c|c|c|c|c|c|c|c|c|c|c|}
\hline \multirow{2}{*}{ PMID\# } & \multirow{2}{*}{ Gender } & \multirow{2}{*}{$\begin{array}{l}\text { Gestation } \\
\text { (Week) }\end{array}$} & \multirow{2}{*}{$\begin{array}{l}\text { Birth Body } \\
\text { Weight (g) }\end{array}$} & \multirow{2}{*}{$\begin{array}{c}\text { Poly } \\
\text { Hydramnios }\end{array}$} & \multirow{2}{*}{$\begin{array}{l}\text { Onset } \\
\text { (Day) }\end{array}$} & \multirow{2}{*}{$\begin{array}{l}\text { Stool Output } \\
(\mathrm{ml} / \mathrm{kg} / \mathrm{d}){ }^{*}\end{array}$} & \multicolumn{3}{|c|}{ Fecal Electrolyte (mmol/L) } & \multirow{2}{*}{$\begin{array}{l}\text { Fecal Osmolarity } \\
\quad(\mathrm{mOsm} / \mathrm{kg} *)\end{array}$} & \multirow{2}{*}{$\begin{array}{c}\text { Fecal PH } \\
\text { Value * }\end{array}$} & \multirow{2}{*}{ Dead/Alive } & \multirow{2}{*}{ Follow-up } \\
\hline & & & & & & & $\mathrm{Na}$ * & $\mathrm{Cl}^{*}$ & $\mathrm{~K}^{*}$ & & & & \\
\hline 28842815 & Male & at term & 3500 & & 3 & & 78 & 64 & 7.3 & & 7 & Dead & 1 month \\
\hline 29546954 & Male & 36 & & No & 10 & 190 & 120 & 67 & & 30 & & Alive & 36 months \\
\hline 25111220 & Female & & & & 150 & & 15 & & & & & Alive & 132 months \\
\hline 23525737 & Male & at term & & & 6 & 150 & & & & & & Alive & 168 months \\
\hline 23354788 & Female & 35 & 2330 & Yes & 1 & & 85 & 78 & 22 & & & Dead & 7 months \\
\hline 23226823 & Female & at term & & No & 3 & 100 & & & & & & Dead & 4 months \\
\hline 22318102 & Female & 35 & 2320 & Yes & 3 & & 35 & 21 & & & & Dead & 23 days \\
\hline 22197941 & Female & at term & 2900 & Yes & 1 & 100 & 78 & 42 & 40 & 11 & & Alive & 4 days \\
\hline 22152886 & Male & 36 & & & 4 & 148 & & & & & & Alive & 41 months \\
\hline 21968248 & Male & at term & 2734 & No & 3 & 175 & 84 & 68 & 13 & & & Alive & 3 months \\
\hline 21299349 & Male & 35 & & & 3 & & & & & & 6 & Dead & 2 months \\
\hline 17418172 & Male & 31 & & & 3 & 100 & 139 & 105 & 4.7 & 279 & & Alive & 12 days \\
\hline 15456973 & Female & at term & 2530 & & 1 & 200 & & & & & & Dead & 1.5 months \\
\hline 11783915 & Male & at term & & & 6 & 115 & 95 & 95 & 30 & 270 & 9 & Alive & 5 months \\
\hline 11414303 & Male & 36 & 2700 & $\mathrm{NO}$ & 2 & 200 & 100 & 60 & 17.5 & & & Alive & 4 months \\
\hline 11251929 & Male & 35 & 3720 & Yes & & 300 & & & & & & Alive & 3 days \\
\hline 11173328 & Male & 36 & 2740 & No & 3 & & 76 & 79 & 39 & & & Dead & 6 months \\
\hline 10941974 & Female & at term & 3510 & & 11 & & 108 & 55 & 11.9 & 330 & & Alive & 39 months \\
\hline 10941971 & Female & 34 & 2100 & No & 6 & 175 & & & & & & Alive & 24 months \\
\hline 9932857 & Female & 36 & & & 10 & 170 & & & & 261 & & Alive & 9 months \\
\hline 9880458 & Male & at term & 3500 & & 6 & 95 & 110 & 85 & 7 & & & Alive & 24 months \\
\hline
\end{tabular}


Table 1. Cont

\begin{tabular}{|c|c|c|c|c|c|c|c|c|c|c|c|c|c|}
\hline \multirow{2}{*}{ PMID\# } & \multirow{2}{*}{ Gender } & \multirow{2}{*}{$\begin{array}{l}\text { Gestation } \\
\text { (Week) }\end{array}$} & \multirow{2}{*}{$\begin{array}{l}\text { Birth Body } \\
\text { Weight (g) }\end{array}$} & \multirow{2}{*}{$\begin{array}{c}\text { Poly } \\
\text { Hydramnios }\end{array}$} & \multirow{2}{*}{$\begin{array}{l}\text { Onset } \\
\text { (Day) }\end{array}$} & \multirow{2}{*}{$\begin{array}{l}\text { Stool Output } \\
(\mathrm{ml} / \mathrm{kg} / \mathrm{d}){ }^{*}\end{array}$} & \multicolumn{3}{|c|}{ Fecal Electrolyte (mmol/L) } & \multirow{2}{*}{$\begin{array}{l}\text { Fecal Osmolarity } \\
\quad\left(\mathrm{mOsm} / \mathrm{kg}^{*}\right)\end{array}$} & \multirow{2}{*}{$\begin{array}{l}\text { Fecal PH } \\
\text { Value * }\end{array}$} & \multirow{2}{*}{ Dead/Alive } & \multirow{2}{*}{ Follow-up } \\
\hline & & & & & & & $\mathrm{Na} *$ & $\mathrm{Cl}$ * & $\mathbf{K}^{*}$ & & & & \\
\hline & Male & at term & 2600 & & 6 & 135 & 81 & 44 & 2 & & & Alive & 96 months \\
\hline & Male & 36 & 3300 & & 6 & 150 & 115 & 96 & 5 & & & Alive & 84 months \\
\hline & Female & at term & 3160 & & 4 & 175 & 107 & 84 & 18 & & & Alive & 48 months \\
\hline & Female & at term & 2700 & & 4 & 100 & 6 & & 27 & & & Dead & 36 months \\
\hline 9844114 & Male & at term & 3300 & No & 1 & 75 & & & & & & Alive & 132 months \\
\hline \multirow[t]{2}{*}{9822319} & Male & 36 & 3090 & No & 1 & 100 & 119 & 111 & 14 & & 6.5 & Alive & 3 months \\
\hline & Male & & & & 14 & 150 & 105 & 74 & 12 & 281 & & Alive & 9 months \\
\hline 9740207 & Male & at term & 3900 & No & 14 & 178 & 105 & 74 & 12.1 & 281 & 8 & Dead & 18 months \\
\hline 9364305 & Female & 36 & 2700 & No & & 175 & & & & & & Alive & 3 months \\
\hline 9323563 & Male & 33 & 2950 & Yes & 1 & & 99 & & 12 & 240 & & Dead & 7 months \\
\hline 8732907 & Male & at term & 3350 & No & 7 & 50 & & & & & & Alive & 7 months \\
\hline \multirow{2}{*}{7959671} & Male & at term & 4200 & No & 14 & 50 & 100 & & & & & Dead & 5 months \\
\hline & Male & at term & 3800 & No & 7 & & 95 & & & & & Alive & 58 months \\
\hline \multirow[t]{2}{*}{8067796} & Male & at term & 3325 & No & 1 & 166 & 58 & 36 & 15 & 309 & & Dead & 9 days \\
\hline & Male & 35 & 2880 & No & 2 & 200 & & & & & & Dead & 4 months \\
\hline 8032396 & Female & 35 & 2810 & No & 3 & 120 & 104 & & 19 & 240 & & Alive & 7 months \\
\hline 1319670 & Female & at term & 2700 & No & 4 & 200 & 6 & & 27 & & & Dead & 37 months \\
\hline \multirow[t]{2}{*}{1660676} & Male & at term & 3530 & Yes & 1 & 150 & 103 & 89 & 19 & & & Alive & 72 months \\
\hline & Male & at term & 3300 & Yes & 1 & 150 & 122 & 102 & 19.4 & & & Alive & 9 months \\
\hline
\end{tabular}


Table 1. Cont.

\begin{tabular}{|c|c|c|c|c|c|c|c|c|c|c|c|c|c|}
\hline \multirow{2}{*}{ PMID\# } & \multirow{2}{*}{ Gender } & \multirow{2}{*}{$\begin{array}{l}\text { Gestation } \\
\text { (Week) }\end{array}$} & \multirow{2}{*}{$\begin{array}{l}\text { Birth Body } \\
\text { Weight (g) }\end{array}$} & \multirow{2}{*}{$\begin{array}{c}\text { Poly } \\
\text { Hydramnios }\end{array}$} & \multirow{2}{*}{$\begin{array}{l}\text { Onset } \\
\text { (Day) }\end{array}$} & \multirow{2}{*}{$\begin{array}{l}\text { Stool Output } \\
(\mathrm{ml} / \mathrm{kg} / \mathrm{d}) *\end{array}$} & \multicolumn{3}{|c|}{ Fecal Electrolyte (mmol/L) } & \multirow{2}{*}{$\begin{array}{l}\text { Fecal Osmolarity } \\
\text { (mOsm/kg *) }\end{array}$} & \multirow{2}{*}{$\begin{array}{c}\text { Fecal PH } \\
\text { Value * }\end{array}$} & \multirow{2}{*}{ Dead/Alive } & \multirow{2}{*}{ Follow-up } \\
\hline & & & & & & & $\mathrm{Na} *$ & $\mathrm{Cl}^{*}$ & $\mathbf{K}^{*}$ & & & & \\
\hline 2759484 & Female & at term & 2300 & No & 3 & 85 & 100 & 82 & 29 & & & Alive & 13 months \\
\hline 3977385 & Female & 34 & 2200 & No & 4 & & 93 & & & & & Dead & 6 months \\
\hline \multirow[t]{2}{*}{25635218} & Female & 36 & 2800 & & 1 & 120 & 83 & & & & 8 & Dead & 9 months \\
\hline & Female & 36 & & & 7 & 100 & & & & & & Alive & 13 months \\
\hline
\end{tabular}

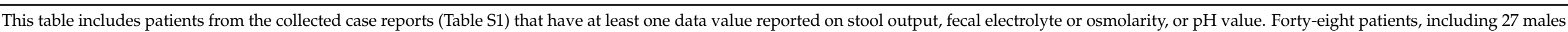

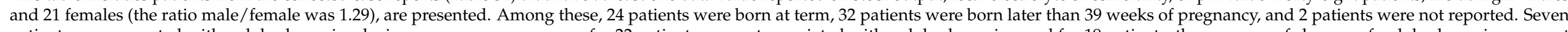

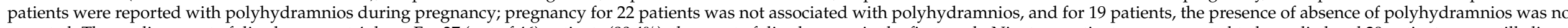

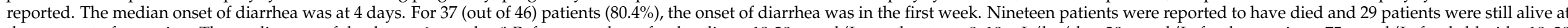

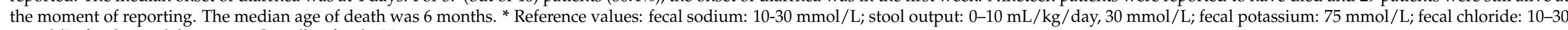
$\mathrm{mmol} / \mathrm{L}$; fecal osmolality: $290 \mathrm{mOsm} / \mathrm{kg}$; fecal $\mathrm{pH}: 7-8$.

Table 2. Summary of the clinical details from published MVID case reports.

\begin{tabular}{|c|c|c|c|c|c|c|c|}
\hline & \multirow[b]{2}{*}{$\begin{array}{l}\text { Birth Body Weight (g) } \\
\qquad n=37\end{array}$} & \multirow[b]{2}{*}{$\begin{array}{l}\text { Stool Output }(\mathrm{ml} / \mathrm{kg} / \mathrm{d}) \\
\qquad n=35\end{array}$} & \multicolumn{3}{|c|}{ Fecal Electrolyte (mmol/L) } & \multirow[b]{2}{*}{$\begin{array}{c}\text { Fecal Osmolarity } \\
(\mathrm{mOsm} / \mathrm{kg}) \\
n=12\end{array}$} & \multirow[b]{2}{*}{$\begin{array}{c}\text { Fecal PH Value } \\
\qquad n=7\end{array}$} \\
\hline & & & $\begin{array}{c}\mathrm{Na}^{+} \\
n=34\end{array}$ & $\begin{array}{c}\mathrm{Cl}^{-} \\
n=23\end{array}$ & $\begin{array}{c}\mathrm{K}^{+} \\
n=25\end{array}$ & & \\
\hline Minimum & 2000 & 50 & 6 & 21 & 2 & 11 & 6 \\
\hline Maximum & 4200 & 300 & 139 & 113 & 40 & 330 & 9 \\
\hline Average & 2987 & 140.2 & 88.8 & 75.0 & 17.8 & 235.3 & 7.36 \\
\hline
\end{tabular}

The minimum, maximum, and average values of birth body weight, stool output, fecal features from Table 1 are displayed. 


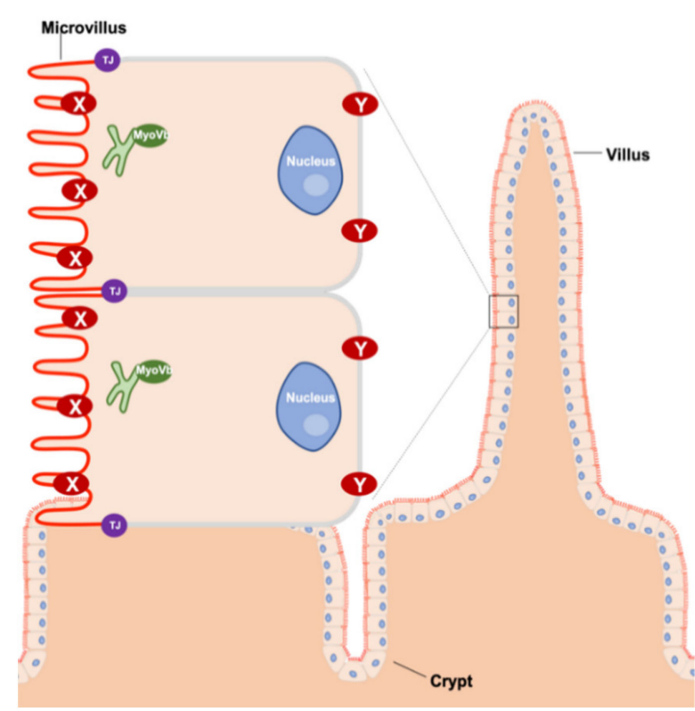

Normal

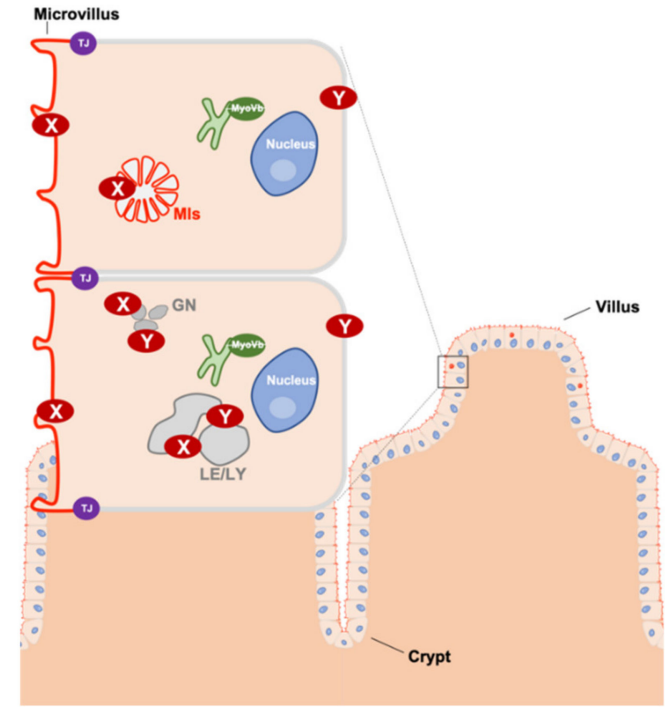

MVID

Figure 1. Schematic overview of tissue and cellular characteristics of healthy and MVID intestinal epithelium. In healthy enterocytes, the recycling endosome (green) is located sub-apically and plays an important role in transporting proteins to the plasma membrane (in particular to the apical membrane). However, in MVID that is caused by the loss function of myosin $\mathrm{Vb}(\mathrm{MyoVb})$, the villi show hypoplasia and microvilli are atrophic. Moreover, the proteins (marked as $\mathrm{X}$ and $\mathrm{Y}$ ) in the plasma membrane are mislocalized in microvillus inclusions (MIs) or in enlarged late endo/lysosomes (LE/LY) and granules (GN). X indicates CD10, DRA, GLUT5, NHE3, SGLT1, sucrase-isomaltase (SI), 5'-nucleotidase (5'NT), alkaline phosphatase (AP), AQP7, CD36, CFTR, DPPIV. Y indicates transferrin receptor (Tfr), $\mathrm{Na}^{+} / \mathrm{K}^{+}$ATPase. TJ: tight junction, MIs: microvillus inclusions, LE: late endosomes, LY: lysosomes, GN: granules.

\subsection{Relation to Other Congenital Diarrheal Disorders}

MVID displays characteristics of other diarrheal disorders. For example, the proteins DRA and NHE3-which show reduced expression and/or are mislocalized in MVID enterocytes $[11,17,21]$ — are mutated in congenital chloride diarrhea (CCD) and congenital sodium diarrhea (CSD), respectively. From all collected case reports (Table S1), we retrieved those that mentioned at least one data value regarding stool output, electrolytes, osmolarity, or $\mathrm{pH}$ value (Table 1). Inspection of fecal electrolyte compositions from the retrieved MVID case reports (Table 2) indicate that the average patient with MVID (fecal $\mathrm{Na}^{+} 89 \mathrm{mEq} / \mathrm{L}, \mathrm{Cl}^{-} 75 \mathrm{mEq} / \mathrm{L}$ ) does not typically fulfil the criteria for the diagnosis of either CSD (fecal Na$\left.{ }^{+}>100 \mathrm{mEq} / \mathrm{L}, \mathrm{Cl}^{-}>40 \mathrm{mEq} / \mathrm{L}\right)$ or CCD $\left(\right.$ fecal Na${ }^{+}>60 \mathrm{mEq} / \mathrm{L}$, $\mathrm{Cl}^{-}>120 \mathrm{mEq} / \mathrm{L}$ ). Further, unlike in CSD and CDD, polyhydramnios (in utero diarrhea) is not common in MVID. However, we found it to be reported in 7 out of 29 cases $(24 \%$; Table 1) for which the presence or absence of polyhydramnios was mentioned. Upon oral or enteral feeding, MVID resembles congenital osmotic diarrhea (characterized by high fecal sodium losses, e.g., congenital glucose-galactose intolerance and congenital sucraseisomaltase deficiency), presumably due to the reduced brush border localization of SGLT-1 and sucrase-isomaltase (SI). MVID thus presents as a mix of other congenital diarrheal and malabsorption disorders.

\subsection{Current Treatment of MVID}

Treatment options are limited. First treatment addresses immediate life-threatening dehydration and metabolic acidosis. Oral rehydration solution (glucose-mediated sodium absorption) is ineffective because of the absence of brush border SGLT-1. Patients with MVID typically require life-long total parenteral nutrition (TPN), also known as hyperali- 
mentation, to compensate for fecal fluid and salt losses and provide nutrients to support growth [22]. Intestinal transplantation is an option [23], but only for specific cases because of its lower 5-year survival rate $(\approx 60 \%)$.

\section{Parenteral Nutrition-Based Interventions in MVID}

While life-saving at first, TPN does not stop the diarrhea and most patients die during infancy because of TPN-associated complications [24]. TPN-related complications are the predominant cause of death in MVID. The most frequent TPN-related complication that causes death of patients with MVID is catheter-related sepsis. Another life-threatening complication of long-term TPN in patients is liver failure (steatosis, cholestasis progressing to cirrhosis) $[23,25]$. This has been attributed to hepatotoxic effects of soybean lipids (rich in omea-6 fatty acids) in the TPN. In a murine model, intravenous administration of omega-3 fatty acid-enriched fish oil-based lipids resulted in less steatosis when compared to omega- 6 fatty acid-rich soybean oil-based lipids. Interestingly, for five patients with MVID, a reduction of liver symptoms was reported when soybean oil-based lipids in the TPN were replaced by fish oil-based lipids [26,27]. While further research is clearly needed to determine which formula will reduce complications, TPN will not be a part of the cure of MVID.

\section{Pharmacological Interventions in MVID}

While no clinical trials for MVID have been reported in the literature or databases (www.clinicaltrials.gov), several pharmacological treatments have been tried with individual patients with MVID and reported in published case reports. In order to review these, we manually screened each of the collected case studies (Table S1) for reports of non-routine pharmacological intervention. This yielded 15 articles reporting a total of 35 patient treatments involving in total 8 different pharmacological interventions (Table 3). The reported pharmacological interventions could be divided from a conceptual point of view into three categories: (i) drugs that stimulate enterocyte proliferation and/or differentiation, (ii) anti-diarrheal drugs that modulate ion balance across the enterocytes' brush border membrane, and (iii) other anti-diarrheal drugs. For all reported treatments, their rationales and outcomes are discussed below. 


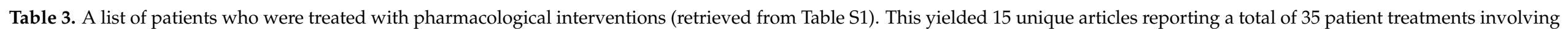

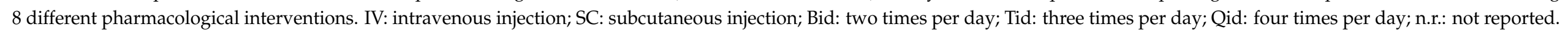

\begin{tabular}{|c|c|c|c|c|c|}
\hline Drug Name & Protocol & Outcome Measures & Result & $\begin{array}{l}\text { Patients } \\
\text { Number }\end{array}$ & PMID \\
\hline EGF & $\begin{array}{c}100 \mathrm{ng} / \mathrm{kg} / \mathrm{h} \text { for two 6-day with a } \\
5 \text {-day rest period between two } \\
\text { courses }\end{array}$ & $\begin{array}{l}\text { Stool volume, small-bowel } \\
\text { mucosal morphometry and } \\
\text { epithelial cell kinetics }\end{array}$ & $\begin{array}{l}\text { No effect except mitotic index in } \\
\text { duodenal crypt increased }\end{array}$ & 1 & 2866310 \\
\hline EGF & $\begin{array}{l}100 \mathrm{ng} / \mathrm{kg} / \mathrm{h}(\mathrm{IV}) \text { for } 5 \text { days, then } \\
\text { followed by same dose for } 21 \text { days } \\
\text { intravenously }\end{array}$ & $\begin{array}{c}24 \mathrm{~h} \text { stool collections, } \\
\text { disaccharidase activity in jejunal } \\
\text { biopsy homogenates and mucosal } \\
\text { epithelial morphometry }\end{array}$ & $\begin{array}{l}\text { No effect except mitotic index in } \\
\text { duodenal crypt increased }\end{array}$ & 1 & 2891946 \\
\hline EGF & $\begin{array}{l}100 \mathrm{ng} / \mathrm{kg} / \mathrm{h}(\mathrm{IV}) \text { for } 21 \text { days, then } \\
\text { followed by same dose for } 21 \text { days } \\
\text { continuous enteral infusion }\end{array}$ & $\begin{array}{c}24 \mathrm{~h} \text { stool collections, } \\
\text { disaccharidase activity in jejunal } \\
\text { biopsy homogenates and mucosal } \\
\text { epithelial morphometry }\end{array}$ & $\begin{array}{l}\text { No effect except mitotic index in } \\
\text { duodenal crypt increased }\end{array}$ & 1 & 2891946 \\
\hline EGF & $100 \mathrm{ng} / \mathrm{kg} / \mathrm{h}$ (IV) for 2 weeks & $\begin{array}{l}\text { Stool volume and small-bowel } \\
\text { mucosal morphometry }\end{array}$ & $\begin{array}{l}\text { No effect except population of } \\
\text { microvilli increased }\end{array}$ & 1 & 9364305 \\
\hline Somatostatin & $100 \mu \mathrm{g}(\mathrm{SC}) \mathrm{Bid}$ for 21 days & Stool volume & $\begin{array}{l}\text { Decreased from } 210 \mathrm{~mL} / \mathrm{kg} / \text { day to } \\
\qquad 150 \mathrm{~mL} / \mathrm{kg} / \text { day }\end{array}$ & 1 & 2759484 \\
\hline Somatostatin & n.r. & Stool volume & Mild decreased & 1 & 1319670 \\
\hline Somatostatin & n.r. & n.r & No effect & 1 & 8114773 \\
\hline Somatostatin & n.r. & n.r. & No effect & 1 & 9323563 \\
\hline Somatostatin & n.r. & n.r. & No effect & 1 & 9880458 \\
\hline Octreotide & $100 \mu \mathrm{g}(\mathrm{SC}) \mathrm{Bid}$ for 14 days & Stool volume & $\begin{array}{l}\text { Decreased from } 275 \mathrm{~mL} / \mathrm{kg} / \text { day to } \\
\qquad 161 \mathrm{~mL} / \mathrm{kg} / \text { day }\end{array}$ & 1 & 2759484 \\
\hline Octreotide & n.r. & n.r. & No effect & 1 & 1993505 \\
\hline Octreotide & n.r. & n.r. & No effect & 2 & 7959671 \\
\hline Octreotide & $4 \mu \mathrm{g} / \mathrm{kg} /$ day & Stool volume & No effect & 2 & 9364305 \\
\hline Octreotide & n.r. & n.r. & No effect & 1 & 11800313 \\
\hline Octreotide & n.r. & n.r. & No effect & 1 & 25635218 \\
\hline
\end{tabular}


Table 3. Cont.

\begin{tabular}{|c|c|c|c|c|c|}
\hline Drug Name & Protocol & Outcome Measures & Result & $\begin{array}{l}\text { Patients } \\
\text { Number }\end{array}$ & PMID \\
\hline Loperamide & $1 \mathrm{mg} / \mathrm{kg} /$ day & n.r. & No effect & 1 & 3977385 \\
\hline Loperamide & $0.1 \mathrm{mg} / \mathrm{kg} /$ day & Stool volume & Decreased remarkably & 1 & 3977385 \\
\hline Loperamide & n.r. & Stool volume & No effect & 1 & 1660676 \\
\hline Loperamide & n.r. & n.r. & No effect & 1 & 7959671 \\
\hline Loperamide & $0.2 \mathrm{mg} / \mathrm{kg}$ Qid & Stool frequency, Bristol stool chart & No effect & 1 & 27682357 \\
\hline Steroid & n.r. & n.r. & No effect & 1 & 7959671 \\
\hline Steroid & $2 \mathrm{mg} / \mathrm{kg} /$ day for 3 weeks & Stool volume & No effect & 1 & 9364305 \\
\hline Prednisolone & n.r. & n.r. & No effect & 1 & 3977385 \\
\hline Dexamethasone & Oral & Stool volume & No effect & 1 & 3977385 \\
\hline Adrenocorticotrophic hormone & n.r. & n.r. & No effect & 1 & 3977385 \\
\hline Hydrocortisone & IV for 4-week & Stool volume & No effect & 1 & 2891946 \\
\hline Cholestyramine & n.r. & Stool volume & No effect & 1 & 1660676 \\
\hline Cholestyramine & n.r. & Stool volume & $\begin{array}{l}\text { Decreased from } 150 \mathrm{mg} / \mathrm{kg} / \text { day to } \\
50 \mathrm{mg} / \mathrm{kg} / \text { day }\end{array}$ & 1 & 9364305 \\
\hline Cholestyramine & n.r. & n.r. & No effect & 1 & 11800313 \\
\hline Pentagastrin & n.r. & n.r & No effect & 1 & 8114773 \\
\hline Racecadotril & $1.5 \mathrm{mg} / \mathrm{kg}$ Tid & Stool frequency, Bristol stool chart & $\begin{array}{l}\text { The mean daily number of stools } \\
\text { fell from } 6.5 \text { to } 2.1 \text { and stool } \\
\text { consistency improved to Bristol } \\
\text { type } 6 .\end{array}$ & 1 & 27682357 \\
\hline Mesenchymal stem cells & $\begin{array}{c}1^{*} 10^{6} \mathrm{U} \text { transduodenal and } \\
2^{*} 10^{6} \mathrm{U}(\mathrm{IV})\end{array}$ & Fluid and electrolyte requirements & $\begin{array}{l}\text { No effect except blood stream } \\
\text { infections were reduced }\end{array}$ & 1 & \\
\hline
\end{tabular}




\subsection{Drugs That Stimulate the Proliferation and/or Differentiation of Enterocytes}

\subsubsection{Epidermal Growth Factor (EGF)}

EGF is a naturally secreted peptide that binds to the EGF receptor on the basal surface of the enterocytes. Binding to the receptor results in the activation of signaling pathways that stimulate cell proliferation and maturation. Given the severe villus hypoplasia in the small intestine of patients with MVID, the rationale for use in MVID was that EGF may stimulate the proliferation of cells in the crypt and in this way would yield more enterocytes to repopulate and thereby regenerate absorptive villi.

Drumm et al [28] reported two patients with MVID that received continuous intravenous infusion at $100 \mathrm{ng} / \mathrm{kg} / \mathrm{h}$. The patients then received the same dosage of EGF for 5 days (case 1) and for 21 days (case 2), followed by the same dose for 21 days intravenously (case 1) or by continuous enteral infusion (case 2). Outcome measures were $24 \mathrm{~h}$ stool collections, disaccharidase activity in jejunal biopsy homogenates, and mucosal epithelial morphometry. The observed increase in crypt cell proliferation indicated that EGF displayed functional activity. However, EGF did not result in increased villus length or clinical improvement. Walker-Schmitz et al [29] reported that one patient received a dosage of $100 \mathrm{ng} / \mathrm{kg} / \mathrm{h}$ EGF for 2 days with 5 days rest period between two courses. Outcome measures were stool volume, small-bowel mucosal morphometry, and epithelial cell kinetics. However, only an increase in crypt cell proliferation was found without other improvements. In a later study, Beck et al [30] tried EGF (100 ng $/ \mathrm{kg} / \mathrm{h}$ for 2 weeks) with one MVID patient and reported some microvillus restoration but no reduction is stool volume.

\subsubsection{Steroids}

Steroids, namely, (gluco)corticosteroids such as prednisolone or hydrocortisone, have been reported to have beneficial effects on the maturation and function of the small intestine in animal models [31]. Six studies reported treatment of a total of eight patients with MVID with steroids but reported no beneficial effects on stool volume [28,30,32-35].

\subsection{Anti-Diarrheal Drugs That Modulate Electrolyte Transport across the Brush Border Membrane 3.2.1. Somatostatin/Octreotide}

Somatostatin is a naturally occurring hormone. Somatostatin binds to somatostatin receptor, which is a $\mathrm{G}_{\mathrm{i}}$-protein-coupled transmembrane receptor. When activated, these inhibit adenylate cyclase (AC) [36]. AC is an enzyme that, downstream of $G_{\alpha}$-coupled receptors at the cell surface, produces adenosine $3^{\prime}, 5^{\prime}$-cyclic monophosphate (cAMP). cAMP, in turn, stimulates the activity and brush border abundance of the CFTR protein and inhibits the function of the NHE3 and DRA proteins [37]. Inhibition of adenylate cyclase, therefore, may be expected to reduce CFTR-mediated secretion of chloride and stimulate NHE3-mediated sodium transport across the brush border surface. Because somatostatin is rapidly degraded by peptidase enzymes in cells and plasma and is poorly absorbed in the gut, continuous intravenous infusion is required but impractical for long-term management. Therefore, the hydrophilic octapeptide octreotide, which is a long-acting somatostatin analogue, has also been used for stool output reduction in patients with high-output secretory diarrhea of various causes [38].

Couper et al [39] reported in one MVID patient a $40 \%$ stool volume decline and reductions in the output of stool electrolytes following subcutaneous octreotide injections (100 $\mu \mathrm{g}$ two times a day for 14 days). In contrast, Schofield et al [40] reported in one MVID patient no beneficial effect of somatostatin. Five other studies reported octreotide as intervention with eight patients with MVID. Beck et al [30] and Raafat et al [33] found no effect of octreotide on stool volume in two patients with MVID per study. Three other studies mentioned octreotide been tried with one patient with MVID per study and reported no beneficial effects [41-43]. Unfortunately, in these latter studies the study protocol and outcome measures were not specified. No follow-ups of any of these treated patients have been reported. 


\subsubsection{Racecadotril}

Racecadotril (acetorphan) is a lipophilic thiorphan derivative and rapidly converted to thiorphan, a potent inhibitor of enkephalinase [44]. Inhibition of enkephalinase prevents the degradation - and thereby increases the biological half-life — of enkephalins, which are endogenous opioid peptides secreted by myenteric and submucosal neurons in the digestive tract. These enkephalins bind and activate $\delta$-opioid receptor on the basal surface of enterocytes, thereby inhibiting AC activity and reducing cAMP levels in the intestinal epithelium. Similarly to somatostatin and octreotide, a resultant reduction in cAMP levels was expected to inhibit CFTR-mediated chloride output and stimulate sodium absorption and, thereby, reduce fluid secretion. Tran et al [45] treated one patient with MVID with racecadotril $(1.5 \mathrm{mg} / \mathrm{kg}$; three times a day) and used stool frequency and the Bristol stool chart indications as outcome measures. Mean daily number of stools was reduced and stool consistency improved. Cessation of nocturnal stooling and improved sleep and appetite was reported by the patient's parents. Withdrawal resulted in more frequent watery stools, which was once again improved after reintroduction of the drug. While promising, since this report, there have been no additional studies reporting on racecadotril in MVID.

\subsubsection{Loperamide}

Loperamide is an opioid receptor agonist and acts on the $\mu$-opioid receptors in the myenteric plexus of the large intestine, thereby decreasing the activity of the myenteric plexus and consequently intestinal motility [46,47]. This results in reduced stool transit time in healthy people, allowing more time for water homeostasis and stool thickening. Loperamide can be prescribed for adults and children above 2 years of age for treatment of acute non-specified diarrhea. The currently prescribed dose of oral loperamide solutions for the treatment of diarrhea in children of 2-5 years of age $(13-20 \mathrm{~kg})$ is a maximal $3 \mathrm{mg} /$ day. Four studies mentioned loperamide intervention with five patients with MVID at varying doses $(0.1-1.0 \mathrm{mg} / \mathrm{kg} /$ day). One patient (receiving the lowest reported dose of $0.1 \mathrm{mg} / \mathrm{kg} /$ day) was reported to display a - non-specified — significant reduction in stool volume [34], whereas no effect was observed in the other patients [32-34,45].

\subsection{Other Anti-Diarrheal Drugs Cholestyramine}

Cholestyramine is a bile acid sequestrant. It is used in the clinic for the symptomatic control of bile acid-induced diarrhea due to short bowel syndrome [48]. One study reported a threefold reduction (from 150 to $50 \mathrm{mg} / \mathrm{kg} /$ day) in stool volume upon treatment of a patient with MVID with an unspecified dose of cholestyramine [30]. Two other studies (also with unspecified doses) with each one patient with MVID found no beneficial effect [32,42].

\section{Discussion and Future Perspectives}

\subsection{Rational Approaches for Pharmacological Treatment of Patients with MVID}

\subsubsection{The AC-Inhibiting Drugs Somatostatin/Octreotide, Loperamide and Racecadotril}

Variable, sometimes promising but overall unsatisfying treatment response with regard to reducing stool volume has been observed in patients with MVID treated with AC-inhibiting compounds (Table 3). Recent analyses of ion transporter deficits in tissues of patients with MVID, MVID cell lines, and animal models [11,17,21,49], in conjunction with new insights in the cAMP-mediated regulation of these transporters [50,51], may offer mechanistic explanations for the variable and overall limited effectiveness of these compounds.

\section{Efficacy of AC-Inhibiting Drugs in MVID}

AC-inhibiting drugs have been shown to be effective in situations where a (pathogeninduced) increase in the concentration of cAMP causes secretory diarrhea. AC-inhibiting drugs can (i) inactivate or stimulate the endocytic removal of NHE3 from the brush border 
surface and thereby inhibit sodium absorption [52], and (ii) stimulate CFTR activity and chloride secretion. In MVID enterocytes, the majority of NHE3 is mislocalized to cytoplasmic vesicles, and MYO5B mutations impair NHE3 trafficking to the brush border surface. This likely limits the expected inhibitory effect of AC-inhibiting compounds on NHE3 and stimulatory effect on sodium absorption [52]. Effects of AC-inhibiting compounds on DRA are hampered by the severely reduced expression of the DRA protein in MVID enterocytes [17]. Loss of DRA activity and elevated luminal chloride will also further reduce NHE3 function, as is seen in CCD patients carrying DRA mutations. Conversely, in the absence of NHE3, DRA function becomes more dependent on CFTR [53], the remaining target of AC-inhibiting drugs. CFTR has been reported to maintain its brush border localization (and even be hyperactivated [54]) in some patients with MVID [17], but not in other patients $[9,55]$. AC-inhibiting compounds may therefore show limited effect in patients with MVID of which enterocytes show mislocalization of CFTR to the cytoplasm. AC-inhibiting compounds could be effective in patients with MVID with (residual) CFTR in the brush borders of their enterocytes. The efficacy will likely depend on the extend of the expression and activity of brush border CFTR. Postnatal surges of glucocorticoids have been suggested to hyperactivate brush border CFTR in MVID enterocytes [54], raising the possibility that AC-inhibiting compounds may be more effective in this period.

\section{Adverse Effects and Limitations of AC-Inhibiting Drugs in MVID}

Although no adverse effects of any of the reported drugs were reported in the case studies, the use of octreotide at high doses or for long-term use in pediatric patients is not without risk. Indeed, one study reported serious adverse effects in 19\% (4 out of 21) of cases [32]. Loperamide is currently not prescribed for children under the age of 2 years due to the risks of respiratory depression and serious cardiac adverse reactions.

\section{Novel Anti-Diarrheal Drugs for MVID}

Novel anti-diarrheal drugs targeted against specific brush border transporter proteins are being developed [56,57], but these have thus far not been tried in MVID. For MVID, the efficacy of CFTR-targeting drugs will depend on the amount and activity of CFTR present at the brush border surface, which varies between patients $[9,17,55]$. Similarly, the effectivity of NHE3-activating peptides depends on the amount of NHE3 at the cell surface, which is limited in most MVID cases where this protein was investigated. The effectivity of drugs or probiotics—such as Lactobacillus acidophilus-aimed at stimulating NHE3 or DRA gene expression $[58,59]$, is therefore likely to be limited by the inability of newly synthesized NHE3 and DRA proteins to maintain sufficient localization at the brush border due to the $M Y O 5 B$ mutations $[14,17,59]$. Interestingly however, recent studies in mice suggested the existence of myosin $\mathrm{Vb}$-independent trafficking routes for brush border proteins including NHE3, which can be stimulated by treatment of enterocytes with lysophosphatidic acid [60-62]. Thus, a drug-stimulated increase in total amount of these transporters at the brush border may be a promising treatment option.

\section{A Genotype-Phenotype Relationship in Treatment Response?}

We found that significant variations have been reported in stool output $(50-300 \mathrm{~mL} / \mathrm{kg} /$ day) and/or in fecal electrolyte compositions between patients (Tables 1 and 2). Whether there is a relationship between the severity of diarrhea and treatment response is not known. The cause of interpatient variations in stool output, stool electrolyte composition, and the precise relative expression and localization pattern of the different ion transporters at the brush border is also not known. Possibly, these reflect the patients' MYO5B mutation. More than 60 unique $M Y O 5 B$ mutations have been identified, with each family carrying distinct sets of $M Y O 5 B$ mutations (www.mvid-central.org) [10,15]. These can differently affect the encoded myosin $\mathrm{Vb}$ protein and, conceivably, brush border protein localization and drug response. A genotype-dependency for the therapeutic efficacy of butyrate was recently reported in CCD patients [63]. Future genotype-phenotype correlation studies 
may shed light on and help predicting treatment responses. There is much interest in the use of patient-specific intestinal organoids for studying genotype-phenotype correlations [64]. While promising, care should be taken as cultured patient organoids may not accurately reflect rapidly changing brush border transporter (e.g., NHE3) profiles during early childhood development.

\subsubsection{The Enterocyte Proliferation- and Differentiation-Stimulating Drugs EGF and} Steroids

It should be emphasized that MVID is both a diarrheal and malabsorption disorder. The prevention of diarrhea in MVID, as such, is likely to improve the management of electrolyte supplementation and reduce the risk of metabolic decompensation. However, it is as such not expected to reduce patients' dependency on TPN and therewith associated mortality. Indeed, chronic diarrhea or malabsorption and villus hypoplasia are not typically correlated, as evidenced by the normal intestinal architecture in CSD, CCD, and congenital glucose-galactose malabsorption patients. Resolving only diarrhea may therefore not be expected to normalize intestinal architecture (i.e., restore villus length).

The remaining villus hypoplasia thus precludes an optimal absorptive epithelium to accommodate oral or enteral nutrient intake. Therefore, in conjunction with the search for effective antidiarrheal treatment, efforts should be directed at restoring villus length. Thus far, drugs such as EGF could stimulate enterocyte proliferation and some differentiation but proved ineffective to ameliorate clinical symptoms in all patients with MVID studied. It was proposed that the villus hypoplasia in MVID reflects (in part) a degeneration triggered by a hitherto unknown factor [28]. A recent study in germline $M y o 5 b$ knockout mice, which showed normal intestinal villi length before birth and villus hypoplasia within days after birth [65], suggests a postnatal factor. The further identification of these postnatal factors may unlock new territories for pharmacological interventions.

\subsection{Practical Aspects of Pharmacological Treatment of Patients with MVID}

Thus far, most drugs have been provided via intravenous or subcutaneous injections. This is not the most practical for children with MVID as they likely require life-long treatment. Orally administered drugs would be more practical. However, oral bioavailability of pharmacological drugs, in particular hydrophilic drugs that require active trans-mucosal transport, is a critical parameter especially in MVID. Indeed, MYO5B mutations cause the downregulation and/or mislocalization of a wide variety of brush border transporters. It should therefore be anticipated that those brush border transporters required for the uptake of hydrophilic drugs such as SLC15A1 (PepT1) may show reduced brush border membrane expression or, in case of proton-dependent transporters, show reduced activity due to impaired NHE3- or v-ATPase-mediated proton secretion in MVID enterocytes. Furthermore, cell surface expression of drug efflux transporters such as the multidrug resistance protein ABCC2 (MRP2) has been shown to be inhibited by MYO5B mutations in the liver of patients with MVID [66,67]. While these drug-transporting cell surface proteins thus far have not been studied in the MVID intestine, alterations in these can be expected to have consequences for pharmacokinetics and optimal drug dosage. Convectional washout of drugs because of the continuous severe diarrhea poses an additional pharmacokinetic hurdle for the oral and enteral administration of both hydrophilic and lipophilic drugs.

With regard to treatment duration and timing, it is recommended that treatment duration is at least 5 days because of the relatively high turnover time of enterocyte. An unsuccessful intervention in a MVID patient with mesenchymal stem cells has been attributed to a treatment that is too short [68]. The timing of pharmacological interventions aimed at specific brush border transporters in young children is important as such transporters show dynamic changes in expression during postnatal development, thereby affecting drug efficacy. In this regard, therapeutic targets identified on the basis of results of patient biopsy analyses that were taken prior to the diagnosis may no longer reflect the situation in the patient's intestine at (later) moments of drug intervention. 


\subsection{Suggestions for Future Reporting}

MVID is a rare disease and large randomized controlled trials are not foreseen. Crossover placebo-controlled n-of- 1 trials may be an appropriate choice given the limited number of available patients with MVID and the chronicity of the condition, provided that the expected treatment response is stable, the onset of the treatment effect is quick, and that carryover effects (depending on drug elimination half-life) are controlled.

Likely, reports of pharmacological interventions will thus continue to typically involve one or few patients per published report. Treatment recommendations will be largely based on clinical experience and anecdotal reporting in the medical literature. To facilitate future meta-analyses of these single patient studies, we recommend that publications include more systematic descriptions of the study protocols (e.g., dosage, dose rationale, intervention duration, administration route, outcome measures, including efficacy and safety parameters) and clinical details (e.g., early/late onset MVID, age, mutation details, baseline measures (e.g., volume, frequency and consistency of diarrhea, fecal electrolytes)).

Supplementary Materials: The following are available online at https:/ / www.mdpi.com/2077-038 3/10/1/22/s1, Table S1: Clinical details from published MVID case reports.

Author Contributions: Conceptualization, C.L. and S.C.D.v.I.; methodology, C.L. and S.C.D.v.I.; writing-original draft preparation, C.L. and S.C.D.v.I.; writing-review and editing, C.L., S.C.D.v.I., E.H.H.M.R., and S.N.d.W.; supervision, S.C.D.v.I. All authors have read and agreed to the published version of the manuscript.

Funding: This research received no external funding.

Conflicts of Interest: The authors declare no conflict of interest.

\section{References}

1. Davidson, G.P.; Cutz, E.; Hamilton, J.R.; Gall, D.G. Familial enteropathy: A syndrome of protracted diarrhea from birth, failure to thrive, and hypoplastic villus atrophy. Gastroenterology 1978, 75, 783-790. [CrossRef]

2. Cutz, E.; Rhoads, J.M.; Drumm, B.; Sherman, P.M.; Durie, P.R.; Forstner, G.G. Microvillus Inclusion Disease: An Inherited Defect of Brush-Border Assembly and Differentiation. N. Engl. J. Med. 1989, 320, 646-651. [CrossRef] [PubMed]

3. Phillips, A.D.; Szafranski, M.; Man, L.-Y.; Wall, W.J. Periodic Acid-Schiff Staining Abnormality in Microvillous Atrophy: Photometric and Ultrastructural Studies. J. Pediatr. Gastroenterol. Nutr. 2000, 30, 34-42. [CrossRef] [PubMed]

4. Groisman, G.M.; Amar, M.; Livne, E. CD10: A valuable tool for the light microscopic diagnosis of microvillous inclusion disease (familial microvillous atrophy). Am. J. Surg. Pathol. 2002, 26, 902-907. [CrossRef]

5. Müller, T.; Hess, M.W.; Schiefermeier, N.; Pfaller, K.; Ebner, H.L.; Heinz-Erian, P.; Ponstingl, H.; Partsch, J.; Röllinghoff, B.; Köhler, H.; et al. MYO5B mutations cause microvillus inclusion disease and disrupt epithelial cell polarity. Nat. Genet. 2008, 40, 1163-1165. [CrossRef]

6. Wiegerinck, C.L.; Janecke, A.R.; Schneeberger, K.; Vogel, G.F.; Van Haaften-Visser, D.Y.; Escher, J.C.; Adam, R.; Thöni, C.E.; Pfaller, K.; Jordan, A.J.; et al. Loss of Syntaxin 3 Causes Variant Microvillus Inclusion Disease. Gastroenterology 2014, 147, 65-68.e10. [CrossRef]

7. Stepensky, P.; Bartram, J.; Amrolia, P.; Weintraub, M.; Debatin, K.-M.; Hoenig, M.; Posovszky, C.; Barth, T.F.; Lehmberg, K.; Walther, P.; et al. Persistent defective membrane trafficking in epithelial cells of patients with familial hemophagocytic lymphohistiocytosis type 5 due to STXBP2/MUNC18-2 mutations. Pediatr. Blood Cancer 2013, 60, 1215-1222. [CrossRef]

8. Vogel, G.F.; Janecke, A.R.; Krainer, I.M.; Gutleben, K.; Witting, B.; Mitton, S.G.; Mansour, S.; Ballauff, A.; Roland, J.T.; Engevik, A.C.; et al. Abnormal Rab11-Rab8-vesicles cluster in enterocytes of patients with microvillus inclusion disease. Traffic 2017, 18, 453-464. [CrossRef]

9. Vogel, G.F.; Van Rijn, J.M.; Krainer, I.M.; Janecke, A.R.; Posovzsky, C.; Cohen, M.C.; Searle, C.; Jantchou, P.; Escher, J.C.; Patey, N.; et al. Disrupted apical exocytosis of cargo vesicles causes enteropathy in FHL5 patients with Munc18-2 mutations. JCI Insight 2017, 2. [CrossRef]

10. Dhekne, H.S.; Pylypenko, O.; Overeem, A.W.; Zibouche, M.; Ferreira, R.J.; Van der Velde, K.J.; Rings, E.H.H.M.; Posovszky, C.; Van der Sluijs, P.; Swertz, M.A.; et al. MYO5B, STX3, and STXBP2 mutations reveal a common disease mechanism that unifies a subset of congenital diarrheal disorders: A mutation update. Hum. Mutat. 2018, 39, 333-344. [CrossRef]

11. Engevik, A.C.; Kaji, I.; Engevik, M.A.; Meyer, A.R.; Weis, V.G.; Goldstein, A.; Hess, M.W.; Müller, T.; Koepsell, H.; Dudeja, P.K.; et al. Loss of MYO5B Leads to Reductions in $\mathrm{Na}^{+}$Absorption with Maintenance of CFTR-Dependent Cl- Secretion in Enterocytes. Gastroenterology 2018, 155, 1883-1897.e10. [CrossRef] [PubMed]

12. Knowles, B.C.; Roland, J.T.; Krishnan, M.; Tyska, M.J.; Lapierre, L.A.; Dickman, P.S.; Goldenring, J.R.; Shub, M.D. Myosin Vb uncoupling from RAB8A and RAB11A elicits microvillus inclusion disease. J. Clin. Investig. 2014, 124, 2947-2962. [CrossRef] [PubMed] 
13. Ruemmele, F.M.; Müller, T.; Schiefermeier, N.; Ebner, H.L.; Lechner, S.; Pfaller, K.; Thöni, C.E.; Goulet, O.; Lacaille, F.; Schmitz, J.; et al. Loss-of-function of MYO5B is the main cause of microvillus inclusion disease: 15 novel mutations and a CaCo-2 RNAi cell model. Hum. Mutat. 2010, 31, 544-551. [CrossRef] [PubMed]

14. Vogel, G.F.; Klee, K.M.; Janecke, A.R.; Müller, T.; Hess, M.W.; Huber, L.A. Cargo-selective apical exocytosis in epithelial cells is conducted by Myo5B, Slp4a, Vamp7, and Syntaxin 3. J. Cell Biol. 2015, 211, 587-604. [CrossRef]

15. Van der Velde, K.J.; Dhekne, H.S.; Swertz, M.A.; Sirigu, S.; Ropars, V.; Vinke, P.C.; Rengaw, T.; Van den Akker, P.C.; Rings, E.H.H.M.; Houdusse, A.; et al. An overview and online registry of microvillus inclusion disease patients and their MYO5B mutations. Hum. Mutat. 2013, 34, 1597-1605. [CrossRef]

16. Dhekne, H.S.; Hsiao, N.-H.; Roelofs, P.; Kumari, M.; Slim, C.L.; Rings, E.H.H.M.; Van Ijzendoorn, S.C.D. Myosin Vb and Rab11a regulate phosphorylation of ezrin in enterocytes. J. Cell Sci. 2014, 127, 1007-1017. [CrossRef]

17. Kravtsov, D.V.; Ahsan, K.; Kumari, V.; Van Ijzendoorn, S.C.D.; Reyes-Mugica, M.; Kumar, A.; Gujral, T.; Dudeja, P.K.; Ameen, N.A. Identification of intestinal ion transport defects in microvillus inclusion disease. Am. J. Physiol. Gastrointest. Liver Physiol. 2016, 311, G142-G155. [CrossRef]

18. Thoeni, C.E.; Vogel, G.F.; Muise, A.M.; Cutz, E.; Huber, L.A.; Tancevski, I.; Geley, S.; Lechner, S.; Pfaller, K.; Hess, M.W.; et al. Microvillus Inclusion Disease: Loss of Myosin Vb Disrupts Intracellular Traffic and Cell Polarity. Traffic 2014, 15, 22-42. [CrossRef]

19. Jayawardena, D.; Alrefai, W.A.; Dudeja, P.K.; Gill, R.K. Recent advances in understanding and managing malabsorption: Focus on microvillus inclusion disease. F1000Research 2019, 8, 2061. [CrossRef]

20. Ruemmele, F.M.; Schmitz, J.; Goulet, O. Microvillous inclusion disease (microvillous atrophy). Orphanet J. Rare Dis. 2006, 1, 22. [CrossRef]

21. Engevik, A.C.; Goldenring, J.R. Trafficking Ion Transporters to the Apical Membrane of Polarized Intestinal Enterocytes. Cold Spring Harb. Perspect. Biol. 2018, 10, a027979. [CrossRef] [PubMed]

22. Phulware, R.H.; Gahlot, G.P.S.; Malik, R.; Gupta, S.D.; Das, P. Microvillous Inclusion Disease as a Cause of Protracted Diarrhea. Indian J. Pediatr. 2019, 86, 854-856. [CrossRef] [PubMed]

23. Ruemmele, F.M.; Jan, D.; Revillon, Y.; Goulet, O.; Lacaille, F.; Cézard, J.-P.; Canioni, D.; Phillips, A.D.; Peuchmaur, M.; Aigrain, Y.; et al. New perspectives for children with microvillous inclusion disease: Early small bowel transplantation. Transplantation 2004, 77, 1024-1028. [CrossRef] [PubMed]

24. Halac, U.; Lacaille, F.; Joly, F.; Hugot, J.-P.; Talbotec, C.; Colomb, V.; Ruemmele, F.M.; Goulet, O. Microvillous Inclusion Disease: How to Improve the Prognosis of a Severe Congenital Enterocyte Disorder. J. Pediatr. Gastroenterol. Nutr. 2011, 52, 460-465. [CrossRef]

25. Girard, M.; Lacaille, F.; Verkarre, V.; Mategot, R.; Feldmann, G.; Grodet, A.; Sauvat, F.; Irtan, S.; Davit-Spraul, A.; Jacquemin, E.; et al. MYO5B and bile salt export pump contribute to cholestatic liver disorder in microvillous inclusion disease. Hepatology 2014, 60, 301-310. [CrossRef]

26. Fuchs, J.; Fallon, E.M.; Gura, K.; Puder, M. Use of an omega-3 fatty acid-based emulsion in the treatment of parenteral nutritioninduced cholestasis in patients with microvillous inclusion disease. J. Pediatr. Surg. 2011, 46, 2376-2382. [CrossRef]

27. Anez-Bustillos, L.; Dao, D.T.; Puder, M.; Potemkin, A.K.; Perez-Atayde, A.R.; Raphael, B.P.; Carey, A.N.; Kamin, D.S.; Thiagarajah, J.R.; Crowley, M.; et al. An Intravenous Fish Oil-Based Lipid Emulsion Successfully Treats Intractable Pruritus and Cholestasis in a Patient with Microvillous Inclusion Disease. Hepatology 2019, 69, 1353-1356. [CrossRef]

28. Drumm, B.; Cutz, E.; Tomkins, K.B.; Cook, D.; Hamilton, J.R.; Sherman, P. Urogastrone/epidermal growth factor in treatment of congenital microvillous atrophy. Lancet 1988, 1, 111-112. [CrossRef]

29. Walker-Smith, J.; Phillips, A.; Walford, N.; Gregory, H.; Fitzgerald, J.; Maccullagh, K.; A Wright, N. Intravenous epidermal growth factor/urogastrone increases small-intestinal cell proliferation in congenital microvillous atrophy. Lancet 1985, 326, 1239-1240. [CrossRef]

30. Beck, N.S.; Chang, Y.S.; Kang, I.S.; Park, W.S.; Lee, H.J.; Suh, Y.L. Microvillus inclusion disease in two Korean infants. J. Korean Med. Sci. 1997, 12, 452-456. [CrossRef]

31. Black, H.E. The Effects of Steroids Upon the Gastrointestinal Tract. Toxicol. Pathol. 1988, 16, 213-222. [CrossRef] [PubMed]

32. Bell, S.W.; A Kerner, J.; Sibley, R.K. Microvillous inclusion disease. The importance of electron microscopy for diagnosis. Am. J. Surg. Pathol. 1991, 15, 1157-1164. [CrossRef] [PubMed]

33. Raafat, F.; Green, N.; Nathavitharana, K.; Booth, I. Intestinal microvillous dystrophy: A variant of microvillous inclusion disease or a new entity? Hum. Pathol. 1994, 25, 1243-1248. [CrossRef]

34. Phillips, A.D.; Jenkins, P.; Raafat, F.; A Walker-Smith, J. Congenital microvillous atrophy: Specific diagnostic features. Arch. Dis. Child. 1985, 60, 135-140. [CrossRef] [PubMed]

35. Cegla, M.; Lohner, M.; E Schaefer, H. Congenital villous atrophy. Disease picture of congenital chronic diarrhea with poor prognosis. Monatsschr. Kinderheilkd. 1993, 141, 925-927. [PubMed]

36. Siperstein, A.E.; Levin, K.E.; Gum, E.T.; Clark, O.H. Effect of somatostatin on adenylate cyclase activity in normal and neoplastic thyroid tissue. World J. Surg. 1992, 16, 555-560. [CrossRef]

37. Li, C.; Naren, A.P. CFTR chloride channel in the apical compartments: Spatiotemporal coupling to its interacting partners. Integr. Biol. 2010, 2, 161-177. [CrossRef]

38. Al-Hussaini, A.; Butzner, D. Therapeutic applications of octreotide in pediatric patients. Saudi J. Gastroenterol. 2012, 18, 87-94. [CrossRef]

39. Couper, R.T.; Berzen, A.; Berall, G.; Sherman, P.M. Clinical response to the long acting somatostatin analogue SMS 201-995 in a child with congenital microvillus atrophy. Gut 1989, 30, 1020-1024. [CrossRef]

40. Schofield, D.E.; Agostini, R.M.; Yunis, E.J. Gastrointestinal Microvillus Inclusion Disease. Am. J. Clin. Pathol. 1992, 98, 119-124. [CrossRef] 
41. Rhoads, J.M.; Vogler, R.C.; Lacey, S.R.; Reddick, R.L.; Keku, E.O.; Azizkhan, R.G.; Berschneider, H.M. Microvillus inclusion disease: In vitro jejunal electrolyte transport. Gastroenterology 1991, 100, 811-817. [CrossRef]

42. Ukarapol, N.; Chotinaruemol, S.; Lertprasertsuk, N.; Wongsawasdi, L. Microvillus inclusion disease as a cause of severe protracted diarrhea in infants. J. Med. Assoc. Thail. 2001, 84, 1356-1360.

43. Mendes, C.; Figueiredo, C.; Mansilha, H.; Proenca, E.; Oliveira, D.; Lima, R.; Carvalho, C. A Case of Protracted Diarrhea in a Newborn: A Diagnostic Challenge. Pediatr. Rep. 2014, 6, 51-52. [CrossRef] [PubMed]

44. Matheson, A.J.; Noble, S. Racecadotril. Drugs 2000, 59, 829-835. [CrossRef] [PubMed]

45. Tran, L.C.; Lazonby, G.; Ellis, D.; Goldthorpe, J.; Iglesias, N.; Steele, J.; Zamvar, V.; Puntis, J.W.; Vora, R. Racecadotril May Reduce Diarrhoea in Microvillous Inclusion Disease. J. Pediatr. Gastroenterol. Nutr. 2017, 64, e25-e26. [CrossRef]

46. Giagnoni, G.; Casiraghi, L.; Senini, R.; Revel, L.; Parolaro, D.; Sala, M.; Gori, E. Loperamide: Evidence of interaction with $\mu$ and $\delta$ opioid receptors. Life Sci. 1983, 33 (Suppl. S1), 315-318. [CrossRef]

47. Ooms, L.A.; Degryse, A.D.; A Janssen, P. Mechanisms of action of loperamide. Scand. J. Gastroenterol. Suppl. 1984, 96, 145-155.

48. Barkun, A.N.; Love, J.; Gould, M.; Pluta, H.; Steinhart, A.H. Bile Acid Malabsorption in Chronic Diarrhea: Pathophysiology and Treatment. Can. J. Gastroenterol. 2013, 27, 653-659. [CrossRef]

49. Engevik, A.C.; Coutts, A.W.; Williams, J.A.; Shub, M.D.; Carlson, D.F.; Melkamu, T.; Goldenring, J.R.; Kaji, I.; Rodriguez, P.; Ongaratto, F.L.; et al. Editing Myosin VB Gene to Create Porcine Model of Microvillus Inclusion Disease, with Microvillus-Lined Inclusions and Alterations in Sodium Transporters. Gastroenterology 2020, 158, 2236-2249.e9. [CrossRef]

50. Singh, V.; Yang, J.; Chen, T.-E.; Zachos, N.C.; Kovbasnjuk, O.; Verkman, A.S.; Donowitz, M. Translating Molecular Physiology of Intestinal Transport into Pharmacologic Treatment of Diarrhea: Stimulation of Na+ Absorption. Clin. Gastroenterol. Hepatol. 2014, 12, 27-31. [CrossRef]

51. Van Ree, J.M.; Verhoeven, W.M.; De Wied, D. Gamma-type endorphins: Neurolepticum-like and antipsychotic action. Prog. NeuroPsychopharmacol. Biol. Psychiatry 1985, 9, 561-567. [CrossRef]

52. Musch, M.W.; Arvans, D.L.; Wang, Y.; Nakagawa, Y.; Solomaha, E.; Chang, E.B. Cyclic AMP-mediated endocytosis of intestinal epithelial NHE3 requires binding to synaptotagmin 1. Am. J. Physiol. Gastrointest. Liver Physiol. 2010, 298, G203-G211. [CrossRef] [PubMed]

53. Tse, C.-M.; Yin, J.; Singh, V.; Sarker, R.; Lin, R.; Verkman, A.S.; Turner, J.R.; Donowitz, M. cAMP Stimulates SLC26A3 Activity in Human Colon by a CFTR-Dependent Mechanism That Does Not Require CFTR Activity. Cell. Mol. Gastroenterol. Hepatol. 2019, 7, 641-653. [CrossRef] [PubMed]

54. Forteza, R.; Ahsan, M.K.; Cartón-García, F.; Arango, D.; Ameen, N.A.; Salas, P.J. Glucocorticoids and myosin5b loss of function induce heightened PKA signaling in addition to membrane traffic defects. Mol. Biol. Cell 2019, 30, 3076-3089. [CrossRef]

55. Ameen, N.A.; Salas, P.J. Microvillus Inclusion Disease: A Genetic Defect Affecting Apical Membrane Protein Traffic in Intestinal Epithelium. Traffic 2000, 1, 76-83. [CrossRef]

56. Thiagarajah, J.R.; Ko, E.; Tradtrantip, L.; Donowitz, M.; Verkman, A.S. Discovery and development of antisecretory drugs for treating diarrheal diseases. Clin. Gastroenterol. Hepatol. 2013, 12, 204-209. [CrossRef]

57. Thiagarajah, J.R.; Donowitz, M.; Verkman, A.S. Secretory diarrhoea: Mechanisms and emerging therapies. Nat. Rev. Gastroenterol. Hepatol. 2015, 12, 446-457. [CrossRef]

58. Singh, V.; Raheja, G.; Borthakur, A.; Kumar, A.; Gill, R.K.; Alakkam, A.; Malakooti, J.; Dudeja, P.K. Lactobacillus acidophilus upregulates intestinal NHE3 expression and function. Am. J. Physiol. Liver Gastrointest. Physiol. 2012, 303, G1393-G1401. [CrossRef]

59. Kumar, A.; Anbazhagan, A.N.; Dudeja, P.K.; Coffing, H.; Chatterjee, I.; Priyamvada, S.; Gujral, T.; Saksena, S.; Gill, R.K.; Alrefai, W.A.; et al. Lactobacillus acidophilus counteracts inhibition of NHE3 and DRA expression and alleviates diarrheal phenotype in mice infected with Citrobacter rodentium. Am. J. Physiol. Gastrointest. Liver Physiol. 2016, 311, G817-G826. [CrossRef]

60. Roland, J.T.; Bryant, D.M.; Datta, A.; Itzen, A.; Mostov, K.E.; Goldenring, J.R. Rab GTPase-Myo5B complexes control membrane recycling and epithelial polarization. Proc. Natl. Acad. Sci. USA 2011, 108, 2789-2794. [CrossRef]

61. Lin, S.; Yeruva, S.; He, P.; Singh, A.K.; Zhang, H.; Chen, M.; Lamprecht, G.; De Jonge, H.R.; Tse, M.; Donowitz, M.; et al. Lysophosphatidic Acid Stimulates the Intestinal Brush Border $\mathrm{Na}^{+} / \mathrm{H}^{+}$Exchanger 3 and Fluid Absorption via LPA5 and NHERF2. Gastroenterology 2010, 138, 649-658. [CrossRef] [PubMed]

62. Kaji, I.; Roland, J.T.; Watanabe, M.; Engevik, A.C.; Goldstein, A.E.; Hodges, C.A.; Goldenring, J.R. Lysophosphatidic Acid Increases Maturation of Brush Borders and SGLT1 activity in MYO5B-deficient Mice, a Model of Microvillus Inclusion Disease. Gastroenterology 2020. [CrossRef] [PubMed]

63. Canani, R.B.; Terrin, G.; Elce, A.; Pezzella, V.; Heinz-Erian, P.; Pedrolli, A.; Centenari, C.; Amato, F.; Tomaiuolo, R.; Calignano, A.; et al. Genotype-dependency of butyrate efficacy in children with congenital chloride diarrhea. Orphanet J. Rare Dis. 2013, 8, 194. [CrossRef] [PubMed]

64. Chen, K.G.; Zhong, P.; Zheng, W.; Beekman, J.M. Pharmacological analysis of CFTR variants of cystic fibrosis using stem cell-derived organoids. Drug Discov. Today 2019, 24, 2126-2138. [CrossRef] [PubMed]

65. Cartón-García, F.; Overeem, A.W.; Nieto, R.; Bazzocco, S.; Dopeso, H.; Macaya, I.; Bilic, J.; Landolfi, S.; Hernandez-Losa, J.; Sc, V.I.; et al. Myo5b knockout mice as a model of microvillus inclusion disease. Sci. Rep. 2015, 5, 12312. [CrossRef]

66. Schlegel, C.; Weis, V.G.; Knowles, B.C.; Lapierre, L.A.; Martin, M.G.; Dickman, P.; Goldenring, J.R.; Shub, M.D. Apical Membrane Alterations in Non-intestinal Organs in Microvillus Inclusion Disease. Dig. Dis. Sci. 2018, 63, 356-365. [CrossRef] 
67. Overeem, A.W.; Li, Q.; Van Ijzendoorn, S.C.; Qiu, Y.; Cartón-García, F.; Leng, C.; Klappe, K.; Dronkers, J.; Hsiao, N.; Wang, J.; et al. A Molecular Mechanism Underlying Genotype-Specific Intrahepatic Cholestasis Resulting from MYO5B Mutations. Hepatology 2020, 72, 213-229. [CrossRef]

68. Onay, O.S.; Tekin, A.N.; Gunes, D.; Aydemir, O.; Artan, S.; Aydemir, Y. GP248 Mesenchymal stem cell therapy in microvillus inclusion disease. Arch. Dis. Child. 2019, 104 (Suppl. S3), A133. [CrossRef] 